\title{
Phylogenetic Relationships among Rhizobium Species Nodulating the Common Bean (Phaseolus vulgaris L.)
}

\author{
PETER VAN BERKUM, ${ }^{1 *}$ DESTA BEYENE, ${ }^{2}$ AND BERTRAND D. EARDLY ${ }^{3}$ \\ Soybean and Alfalfa Research Laboratory, Agricultural Research Service, BARC-West, U.S. Department of Agriculture, \\ Beltsville, Maryland 20705'; Holetta Agricultural Research Center, Institute of Agricultural Research, \\ Addis Ababa, Ethiopia ; and Penn State Berks Campus, Reading, Pennsylvania $19610^{3}$
}

\begin{abstract}
The phylogenetic relationships among Rhizobium species that nodulate Phaseolus vulgaris (common bean) were determined by directly sequencing the amplified $16 \mathrm{~S}$ ribosomal DNA genes of these organisms. The bean strains formed four separate clusters. One cluster was composed of Rhizobium leguminosarum bv. trifolii, $R$. leguminosarum bv. viciae, and $R$. leguminosarum bv. phaseoli. Two other clusters comprised Rhizobium etli and Rhizobium tropici, and the fourth cluster contained a single bean-nodulating strain. Data for species identification were obtained from DNA-DNA reassociation experiments. The levels of DNA relatedness among strains belonging to the three biovars of $R$. leguminosarum ranged from 58 to $67 \%$. The levels of DNA relatedness between $R$. leguminosarum bv. phaseoli and $R$. etli and $R$. tropici ranged from 43 to $45 \%$ and 13 to $16 \%$, respectively. The levels of DNA relatedness between the strain belonging to the fourth cluster and strains of the other three Rhizobium species that nodulate beans were less than $10 \%$.
\end{abstract}

Phaseolus vulgaris L. (common bean) is an agriculturally important legume crop which benefits from a symbiosis with bacteria belonging to the genus Rhizobium. The rhizobia that infect host legumes, such as peas, clovers, and common beans, have been placed in a single species, Rhizobium leguminosarum. This species has been subdivided into three biovars largely on the basis of specificity for host plant infection and nodulation (12). Jordan (12) noted that of the three biovars of $R$. leguminosarum, $R$. leguminosarum bv. phaseoli was more distinct than the other two. The reasons for this became apparent when the heterogeneity of strains classified as members of $R$. leguminosarum bv. phaseoli was described (3). Bean isolates obtained from English fields are only weakly polymorphic (26). In contrast, wide phenotypic and genotypic variations have been reported among strains originating in the Americas $(16,17,19,20)$.

Bean strains that originated in Mexico and South America were identified as members of a heterogeneous complex of strongly differentiated phylogenetic lineages, and the data indicated that several species should be recognized (19). One of the deep lineages was subsequently classified as Rhizobium tropici (17). On the basis of $16 \mathrm{~S}$ ribosomal DNA (rDNA) gene sequences, Willems and Collins (25) showed that the phylogenetic position of $R$. tropici was distinct from that of $R$. leguminosarum. However, their analysis was with reference to a clover strain, strain ATCC 14480, because the 16S rDNA sequences of $R$. leguminosarum bv. phaseoli had not been determined and were not available.

Until recently, all bean strains other than $R$. tropici were classified as $R$. leguminosarum. However, there are a number of differences between the nucleotide sequences of a partial analysis of the $16 \mathrm{~S}$ rDNA genes of bean strains of American origin and the sequence of $R$. leguminosarum bv. viciae type strain ATCC 10004. This finding led to the suggestion that the bean strains of American origin should be referred to as Rhizobium

* Corresponding author. Mailing address: Soybean and Alfalfa Research Laboratory, Agricultural Research Service, HH-19, Bldg. 011, BARC-West, U.S. Department of Agriculture, Beltsville, MD 20705. Phone: (301) 504-7280. Fax: (301) 504-5728. Electronic mail address: PBERKUM@ASRR.ARSUSDA.GOV. sp. type I strains rather than $R$. leguminosarum bv. phaseoli (3). Subsequently, a closer examination of several strains that originated from beans grown in the Americas led to reclassification of Rhizobium sp. type I as Rhizobium etli (20). This distinction was based primarily on the sequence differences in a 260-bp region of the $16 \mathrm{~S}$ rDNA genes. The phylogenetic relatedness of the 16S rDNA alleles of $R$. etli, the bean-nodulating $R$. leguminosarum strains, and $R$. tropici has not been determined.

Since Rhizobium species that were isolated from many different genera and species of wild legumes nodulate Phaseolus vulgaris $(1,26)$, the phylogenetic relatedness of the different species of bean-nodulating rhizobia should be determined. In this study our objective was to determine the phylogenetic positions of $R$. etli and $R$. leguminosarum bv. phaseoli by using $16 \mathrm{~S}$ rDNA sequencing and DNA reassociation analyses. We also determined the phylogenetic relatedness of $R$. leguminosarum bv. viciae type strain USDA 2370 (= ATCC 10004) to strains of other biovars of $R$. leguminosarum.

\section{MATERIALS AND METHODS}

Bacterial strains. The strains used in this study are listed in Table 1. Strains CIAT 899, CFN 299, CFN 42, and USDA 2370 were used because they are the type strains of $R$ tropici type $\mathrm{B}, R$ tropici type A, $R$ etli, and $R$ leguminosarum, respectively $(3,7,17,20,23)$. Clover (Trifolium pratense) strain ATCC 14480 was included because it is the only $R$. leguminosarum strain whose complete $16 \mathrm{~S}$ rDNA sequence has been determined (25). Since bean strains originating in England share enzyme genotypes with $R$. leguminosarum bv, viciae and $R$. leguminosanum bv. trifolii (26), we used two strains from the Rothamsted collection to represent $R$. leguminosanum bv, phaseoli. Strain RCR 3644 is a recommended inoculant strain and was isolated from a bean plant growing in a field in Cambridge, England. Strain RCR 3618D is the only other strain available from the Rothamsted collection which originated from a different location. Strain TAL 182 was used as an additional representative of $R$. etli because of genetic differences with strain CFN $42^{\mathrm{T}}$ ( $\mathrm{T}=$ type strain) $(2,23)$.

PCR amplification and sequence analysis of the $16 \mathrm{~S}$ rDNA gene. Colonies of the bacteria grown on the surface of solid modified arabinose-gluconate medium (22) were placed in $200-\mu$ l portions of $0.1 \%$ Tween 20 (polyoxythylene sorbitan monolaurate), and the cells were lysed by incubating the suspensions at $95^{\circ} \mathrm{C}$ for 10 min. Samples $(5 \mu 1)$ of these preparations were used in $120-\mu$ I PCR mixtures containing primers $\mathrm{fD} 1$ and $\mathrm{rD} 1(25)$, which had been synthesized without linker sequences for cloning. The reaction mixtures, which contained 10 pmol of each primer, each deoxynucleoside triphosphate at a concentration of $10 \mathrm{mM}$, and 100 $\mathrm{mM} \mathrm{MgCl}$ in $16 \mathrm{~S}$ rDNA PCR buffer $(1 \%$ Triton $\mathrm{X}-100,50 \mathrm{mM} \mathrm{KCl}, 10 \mathrm{mM}$ Tris; $\mathrm{pH} 9.0$ ) were pretreated at $95^{\circ} \mathrm{C}$ for $3 \mathrm{~min}$ before $3 \mathrm{U}$ of Taq DNA polymerase (Promega Corp., Madison, Wis.) was added. The following conditions were used for DNA amplification: 35 cycles consisting of denaturation at 
TABLE 1. Strains used in this study

\begin{tabular}{|c|c|c|c|}
\hline Strain & Other designation(s) & Geographical origin & Source or reference ${ }^{\prime \prime}$ \\
\hline R. leguminosarum bv. viciae USDA $2370^{\top}$ & $\operatorname{ATCC} 10004^{\mathrm{T}}$ & Illinois & USDA \\
\hline R. leguminosanum bv. trifolii ATCC 14480 & USDA 2145, LMG 8820 & Unknown & USDA \\
\hline R. leguminosarum bv. phaseoli RCR 3644 & USDA 2671 & England & RCR \\
\hline R. etli CFN $42^{\mathrm{T}}$ & USDA $9032^{\mathrm{T}}$ & Mexico & 18 \\
\hline R. etli TAL 182 & USDA 9041 & Hawaii & 18 \\
\hline R. tropici CFN $299^{\mathrm{T}}$ & USDA $9039^{\top}$ & Brazil & 18 \\
\hline R. tropici CIAT $899^{\mathrm{T}}$ & USDA $9030^{\mathrm{T}}$ & Colombia & 18 \\
\hline
\end{tabular}

${ }^{a}$ USDA, U.S. Department of Agriculture Agricultural Research Service National Rhizobium Culture Collection; RCR, Rothamsted Collection of Rhizohium.

$94^{\circ} \mathrm{C}$ for $1 \mathrm{~min}$, annealing at $55^{\circ} \mathrm{C}$ for $1 \mathrm{~min}$, and extension at $72^{\circ} \mathrm{C}$ for $2 \mathrm{~min}$, followed by a final extension step for $3 \mathrm{~min}$ in a thermocycler (Perkin-Elmer Cetus, Norwalk, Conn.). The PCR products $(100 \mu \mathrm{l})$ were purified by using QIAquick Spin columns (Oiagen, Inc., Chatsworth, Calif.) and were sequenced by using a model 370A DNA sequencer (Applied Biosystems, Inc., Foster City, Calif.) and a Taq DyeDeoxy terminator cycle sequencing kit (Applied Biosystems). The forward sequencing primers used spanned Escherichia coli positions 6 to 25,339 to 357,515 to 530,785 to 805,1097 to 1114 , and 1391 to 1406 , and the reverse sequencing primers used spanned positions 1449 to 1435,1406 to 1392,1242 to 1226,1115 to 1100,926 to 907,802 to 785,536 to 519,358 to 342 , and 126 to $110(24)$.

Analysis of the sequence data. The aligned sequences (6) were analyzed by using the SEQBOOT, DNADIST, FITCH, and CONSENSE programs (4). Trees were constructed by using the programs DRAWTREE and RETREE (4).

Bacterial growth, DNA extraction, agarose gel electrophoresis, and DNA relatedness analysis. Cultures were grown in $50-\mathrm{ml}$ portions of modified arabinosegluconate medium to isolate genomic DNAs (22). Genomic DNA was extracted from washed cells and purified by $\mathrm{CsCl}$ centrifugation as described previously (18). Samples $(10 \mu \mathrm{g})$ were digested with restriction endonuclease EcoRI (Bethesda Research Laboratories, Gaithersburg, Md.) as recommended by the manufacturer at $37^{\circ} \mathrm{C}$ for $16 \mathrm{~h}$. The restriction fragments $(1.0 \mu \mathrm{g}$ per lane), which were separated on $0.7 \%$ agarose gels, were depurinated, denatured, and transferred to Nytran membranes (Schleicher \& Scheull, Inc., Keene, N.H.) (18). Southern hybridization analysis was done as described previously (18), except that the final wash of the membranes was in an aqueous solution containing $0.2 \times$ SSC ( $1 \times$ SSC is $0.15 \mathrm{M} \mathrm{NaCl}$ plus $0.015 \mathrm{M}$ sodium citrate) and $0.1 \%$ sodium dodecyl sulfate for $1 \mathrm{~h}$ at $65^{\circ} \mathrm{C}$. The probes used were genomic DNAs $(0.13 \mu \mathrm{g})$ from strains USDA $2370^{\mathrm{T}}$, RCR 3644, CFN $42^{\mathrm{T}}$, and RCR 3618D that had been labelled with $\left[{ }^{32} \mathrm{P}\right] \mathrm{dCTP}$ ) by using a random prime labelling kit (U.S. Biochemicals, Cleveland, Ohio). The reaction mixture recommended for DNA fragments isolated in low-melting-point agarose gels was used, and the mixtures were incubated at $37^{\circ} \mathrm{C}$ for $3 \mathrm{~h}$. The membranes were autoradiographed so that the autoradiogram could be used as a guide to cut the lanes from the membranes. Each lane was immersed in $3 \mathrm{ml}$ of scintillation fluid, and the radioactivity was measured with a scintillation counter (Packard model 2200CA Tri-Carb liquid scintillation analyzer). Each strain was analyzed twice with each probe, and the amount of radioactivity associated with each lane was determined twice. The levels of DNA relatedness between each strain and strains USDA $2370^{\mathrm{T}}$. RCR 3644 , CFN $42^{\mathrm{T}}$, and RCR $3618 \mathrm{D}$ were expressed as percentages of the counts associated with the control lanes.

Nucleotide sequence accession numbers. The 16S rDNA sequences of strains CFN $42^{\mathrm{T}}$, TAL 182, USDA 2370 ${ }^{\mathrm{T}}$, RCR 3618D, and RCR 3644 have been deposited in the GenBank database under accession numbers U28916, U28939, U29386, U29387, and U29388, respectively.

\section{RESULTS}

Nucleotide sequence analysis. None of the sequences was identical to any other sequence examined (Table 2). The minimum and maximum numbers of nucleotide differences were 3 and 41 , which represented similarity values ranging from 99.8 to $97.1 \%$. The $16 \mathrm{~S}$ rDNA sequences of the two strains of $R$. etli were $99.6 \%$ similar. The levels of similarity between the $16 \mathrm{~S}$ rDNA sequence of strain RCR $3618 \mathrm{D}$ and the $16 \mathrm{~S}$ rDNA sequences of the other seven strains examined ranged from $98.7 \%$ with strain ATCC 14480 to $97.1 \%$ with strain CFN $299^{\mathrm{T}}$. The levels of similarity between the strain RCR 3618D $16 \mathrm{~S}$ rDNA sequence and the $R$. etli TAL 182 and CFN 42 ${ }^{\mathrm{T}} 16 \mathrm{~S}$ rDNA sequences were 98.2 and $97.9 \%$, respectively.

The five sequences which we determined were aligned with the sequences of 25 reference strains belonging to the $\alpha-2$ subclass of the Proteobacteria. A distance matrix obtained by using the Jukes-Cantor model of nucleotide substitution (13)

TABLE 2. Numbers of nucleotide differences in the aligned $16 \mathrm{~S}$ rDNA sequences of $R$. leguminosarum, $R$. etli, $R$. tropici, and strain RCR 3618D isolated from Phaseolus vulgaris

\begin{tabular}{|c|c|c|c|c|c|c|c|}
\hline \multirow[b]{2}{*}{ Strain } & \multicolumn{7}{|c|}{ No. of nucleotide differences" } \\
\hline & 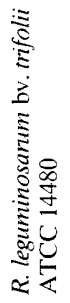 & 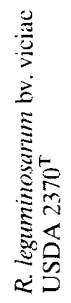 & 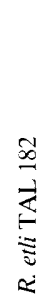 & 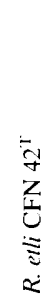 & 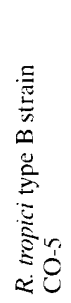 & 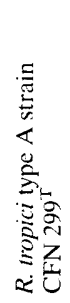 & 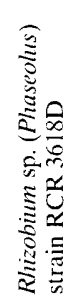 \\
\hline R. leguminosarum bv. phaseoli RCR 3644 & 3 & 4 & 12 & 16 & 30 & 31 & 22 \\
\hline R. leguminosarum bv. trifolii ATCC 14480 & & 3 & 11 & 15 & 27 & 28 & 19 \\
\hline R. leguminosarum bv. viciae USDA $2370^{\mathrm{T}}$ & & & 12 & 16 & 30 & 31 & 22 \\
\hline R. etli TAL 182 & & & & 6 & 34 & 35 & 26 \\
\hline R. etli CFN $42^{\mathrm{T}}$ & & & & & 34 & 33 & 30 \\
\hline R. tropici type B strain C-O5 & & & & & & 10 & 38 \\
\hline R. tropici type A strain CFN $299^{\mathrm{T}}$ & & & & & & & 41 \\
\hline Rhizobium sp. (Phaseolus) strain RCR 3618D & & & & & & & \\
\hline
\end{tabular}

\footnotetext{
${ }^{a}$ The number of nucleotides in the aligned sequences was 1,533 . Gap sites and missing information were removed before the numbers of nucleotide differences were
} determined. 


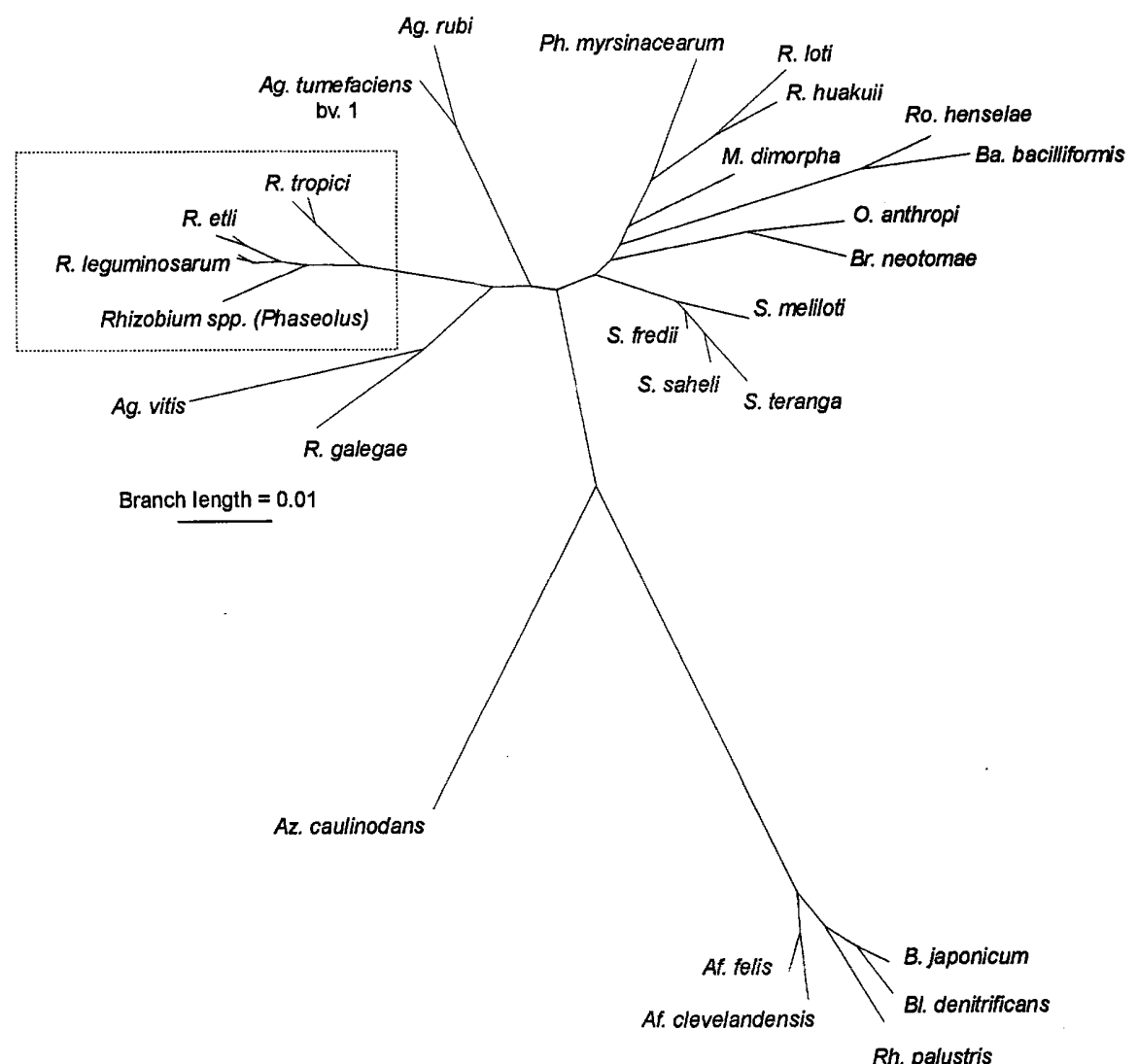

FIG. 1. Optimal unrooted phylogenetic tree obtained by using the Fitch-Margoliash tree selection criteria when Jukes-Cantor distances were estimated from $16 \mathrm{~S}$ rDNA sequence data. This tree shows the relationships of $R$. leguminosarum, $R$. etli, $R$. tropici and Rhizobium sp. (Phaseolus) with several related taxa belonging to the $\alpha-2$ subgroup of the Proteobacteria. The taxa used in this analysis were Bradyrhizobium japonicum (B. japonicum) (GenBank accession number Z35330), Blastobacter denitrificans (Bl. denitrificans) (S46917), Rhodopseudomonas palustris (Rh. palustris) (D25312), Afipia felis (Af. felis) (M65248), Afipia clevelandensis (Af. clevelandensis) (M69186), Azorhizobium caulinodans (Az. caulinodans) (X67221), Sinorhizobium fredii (S. fredii) (X67231), Sinorhizobium meliloti (S. meliloti) (X67222), Sinorhizobium saheli (S. saheli) (X68390), Sinorhizobium teranga (S. teranga) (X68387), Brucella neotomae (Br. neotomae) (L26167), Ochrobactrum anthropi (O. anthropi) (D12794), Bartonella bacilliformis (Ba. bacilliformis) (M65249), Rochalimaea henselae (Ro. henselae) (M73229), Mycoplana dimorpha (M. dimorpha) (D12786), Phyllobacterium myrsinacearum (Ph. myrsinacearum) (D12789), Agrobacterium rubi (Ag. rubi) (X67228), Agrobacterium tumefaciens biovar 1 (Ag. tumefaciens bv. 1) (D14500), Agro-bacterium vitis (Ag. vitis) (X67225), Rhizobium huakuii (R. huakuii) (D13431), Rhizobium loti (R. loti) (X67229), Rhizobium tropici (R. tropici) (X67233 and X67234), Rhizobium leguminosanum bv, trifolii (R. leguminosarum) (X67227), and Rhizobium galegae (R. galegae) (X67226). The fine branches in the box are resolved in Fig. 2.

was used to construct an unrooted tree by the Fitch-Margoliash method (5). The bean-nodulating strains clustered together and along with $R$. leguminosarum diverged beyond the branch points of three Agrobacterium species and Rhizobium galegae (Fig. 1). The strains representing the three biovars of $R$. leguminosarum formed a tight cluster (Fig. 2). The strain RCR $3618 \mathrm{D}$ branch was located in between the branch points of $R$. etli and $R$. tropici (Fig. 2).

DNA relatedness. The levels of DNA relatedness of the three strains of $R$. leguminosarum ranged from 58 to $67 \%$ (Table 3). The levels of DNA relatedness between $R$. leguminosarum bv. phaseoli RCR 3644 and $R$. etli and $R$. tropici were less than $60 \%$. The level of DNA relatedness for the two strains of $R$. etli was $60 \%$, while the levels of DNA relatedness between $R$. etli CFN $42^{\mathrm{T}}$ and $R$. tropici type A and $\mathrm{B}$ strains were less than $10 \%$. The levels of DNA relatedness between strain RCR 3618D and the other seven strains were less than $10 \%$ (Table 3).

\section{DISCUSSION}

A combination of 16S rDNA sequence and DNA relatedness data indicated that Phaseolus vulgaris is nodulated by at

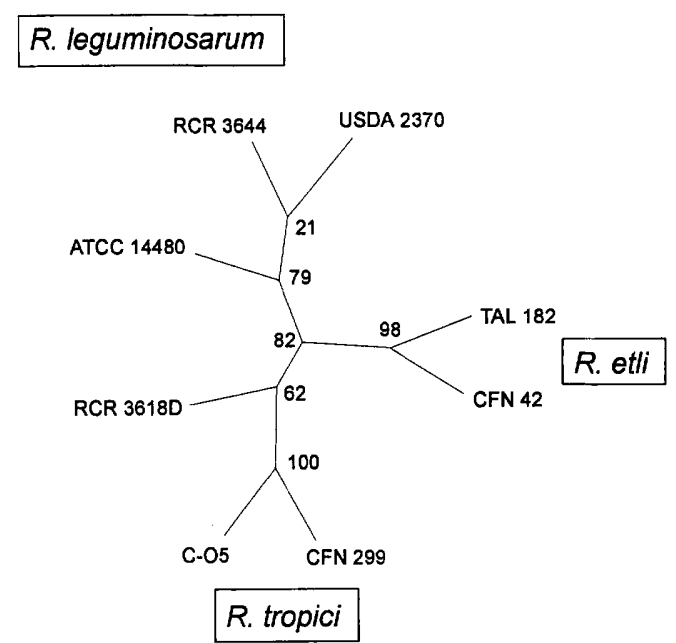

FIG. 2. Unrooted majority rule consensus tree based on 1,000 bootstrap replicates. Optimal trees for each bootstrap data set were obtained by using the Fitch-Margoliash tree selection criteria when Jukes-Cantor distances were estimated from $16 \mathrm{~S}$ rDNA sequence data. The number at each internal node indicates the level of support in the data for the presence of that node. 
TABLE 3. Levels of DNA relatedness for strains of

$R$. leguminosanum, bv. viciae, $R$. leguminosarum bv. phaseoli, $R$. etli, $R$. tropici, and strain RCR

3618D isolated from Phaseolus vulgaris

\begin{tabular}{|c|c|c|c|c|}
\hline \multirow[b]{2}{*}{ Strain } & \multicolumn{4}{|c|}{$\%$ DNA relatedness with: } \\
\hline & $\begin{array}{l}\text { Strain } \\
\text { USDA } \\
2370^{\mathrm{T}}\end{array}$ & $\begin{array}{c}\text { Strain } \\
\text { RCR } \\
3644\end{array}$ & $\begin{array}{c}\text { Strain } \\
\text { CFN } \\
42^{\mathrm{T}}\end{array}$ & $\begin{array}{c}\text { Strain } \\
\text { RCR } \\
3618 \mathrm{D}\end{array}$ \\
\hline R. leguminosanum USDA $2370^{\mathrm{T}}$ & 100 & 58 & 26 & 6 \\
\hline ATCC 14480 & 60 & 67 & 22 & 6 \\
\hline RCR 3644 & 58 & 100 & 28 & 7 \\
\hline RCR 3618D & 10 & 13 & 14 & 100 \\
\hline R. etli CFN 42 & 32 & 45 & 100 & 8 \\
\hline R. etli TAL 182 & 28 & 43 & 60 & 9 \\
\hline R. tropici CIAT $899^{\mathrm{T}}$ & 12 & 16 & 6 & 2 \\
\hline R. tropici CFN $299^{\mathrm{T}}$ & 10 & 13 & 7 & 3 \\
\hline
\end{tabular}

least four different Rhizobium species, including $R$. leguminosarum, $R$. etli, $R$. tropici, and an unnamed species represented by strain RCR 3618D. Although the levels of $16 \mathrm{~S}$ rDNA sequence similarity among the strains were relatively high, the DNA relatedness data indicated that these organisms belong to separate species.

Young (26) observed the same chromosomal genotypes, as determined by multilocus enzyme electrophoresis, in isolates obtained from peas (Pisum sativum), clover (Trifolium species), and beans (Phaseolus vulgaris). The conclusion that $R$. leguminosarum nodulates beans was supported by the identical nucleotide sequences of a 260 -bp fragment of the $16 \mathrm{~S}$ rDNA genes of strain 8002 and the type strain of $R$. leguminosarum (3). Because the levels of DNA relatedness between beannodulating Rhizobium strains and $R$. leguminosarum were only 37 to $50 \%$, Jarvis et al. (10) suggested that the bean strains were members of a species separate from $R$. leguminosarum. Subsequently, Crow et al. (1) concluded that the bean strains did not represent a sufficiently distinct population to warrant separation from $R$. leguminosarum, but also recognized the possibility that there are distinct genetic groups that nodulate beans. Both the $16 \mathrm{~S}$ rDNA sequence data and the DNA relatedness data confirmed that one of these groups is R. leguminosarum, which was represented in our study by strain RCR 3644 .

We studied strain TAL 182 in addition to strain CFN $42^{\mathrm{T}}$ because these two strains of $R$. etli produce different electrophoretic patterns following PCR when primers for REP and ERIC sequences are used (23) and their genetic distance is approximately 0.6 as determined from variations in their allele profiles when multilocus enzyme electrophoresis is used (2, 19). Even though these two strains differ significantly, their $16 \mathrm{~S}$ rDNA nucleotide sequences are similar and a DNA relatedness value of $60 \%$ indicates that they belong to the same species.

Of the three bean-nodulating Rhizobium species that we analyzed, only $R$. leguminosarum bv. phaseoli and $R$. tropici occur in European soils (1). However, French soils may contain two additional bean-nodulating Rhizobium species, which have been referred to as species H152 (14) and species R602 (8).

The levels of $16 \mathrm{~S}$ rDNA nucleotide sequence similarity between RCR 3618D and the other bean strains ranged from 98.4 to $97.1 \%$ ( 22 to 41 base pair differences). These values are comparable to the $16 \mathrm{~S}$ rDNA nucleotide similarity values obtained for the different Sinorhizobium species (99.2 to 97.6\%) and the value obtained for Rhizobium loti and Rhizobium huakuii $(15)(98.3 \%)$. Therefore, the levels of $16 \mathrm{~S}$ rDNA nucle- otide similarity between RCR $3618 \mathrm{D}$ and the other bean rhizobia are similar to the levels of $16 \mathrm{~S}$ rDNA similarity between species of other root nodule bacteria, indicating that RCR $3618 \mathrm{D}$ should be retained in the same genus as $R$. leguminosarum, $R$. etli, and $R$. tropici. However, these interspecies $16 \mathrm{~S}$ rDNA nucleotide similarity values are greater than $97.0 \%$, the value above which the usefulness of $16 \mathrm{~S}$ rDNA sequences in species assignment has been questioned and DNA-DNA reassociation data are essential (21). The levels of DNA relatedness values between strain RCR 3618D and the other Rhizobium species examined were less than $10 \%$, indicating that RCR 3618D represents a different species since the same or closely related species generally exhibit levels of DNA homology ranging from 60 to $100 \%$ (11). However, we decided not to name the species represented by RCR 3618D at this time and to wait until additional isolates are identified and compared with previously described Rhizobium species by the criteria outlined by Graham et al. (9).

\section{ACKNOWLEDGMENTS}

We especially thank William G. Weisburg, Gene-Trak Systems, for his help with choosing the primers used for 16S rDNA gene sequencing. We also thank Perry B. Cregan for synthesizing the primers and $\mathrm{K}$. Lee Nash for expert technical assistance.

\section{REFERENCES}

1. Crow, V. L., B. D. Jarvis, and R. M. Greenwood. 1981. Deoxyribonucleic acid homologies among acid-producing strains of Rhizobium. Int. J. Syst. Bacteriol. 31:152-172.

2. Eardly, B. D., F.-S. Wang, T. S. Whittam, and R. K. Selander. 1995. Species limits in Rhizobium populations that nodulate the common bean (Phaseolus vulgaris). Appl. Environ. Microbiol. 61:507-512.

3. Eardly, B. D., J. P. W. Young, and R. K. Selander. 1992. Phylogenetic position of Rhizobium sp. strain Or 191, a symbiont of both Medicago sativa and Phaseolus vulgaris, based on partial sequences of the 16S rRNA and nifH genes. Appl. Environ. Microbiol. 58:1809-1815.

4. Felsenstein, J. 1993. PHYLIP (phylogenetic inference package), version 3.5c. Department of Genetics, University of Washington, Seattle.

5. Fitch, W. M., and E. Margoliash. 1967. Construction of phylogenetic trees. Science 155:279-284.

6. Genetics Computer Group. 1991. Program manual for the GCG package, version 7. Genetics Computer Group, Madison, Wis.

7. Geniaux, E., M. Flores, R. Palacios, and E. Martinez. 1995. Presence of megaplasmids in Rhizobium tropici and further evidence of differences between the two R. tropici subtypes. Int. J. Syst. Bacteriol. 45:392-394.

8. Geniaux, E., G. Laguerre, and N. Amager. 1993. Comparison of geographically distant populations of Rhizobium isolated from root nodules of Phaseolus vulgaris. Mol. Ecol. 2:295-302.

9. Graham, P. H., M. J. Sadowsky, H. H. Keyser, Y. M. Barnet, R. S. Bradley, J. E. Cooper, J. De Ley, B. D. W. Jarvis, E. B. Roslycky, W. B. Strijdom, and J. P. W. Young. 1991. Proposed minimal standards for the description of new genera and species of root- and stem-nodulating bacteria. Int. J. Syst. Bacteriol. 41:582-587.

10. Jarvis, B. D. W., A. G. Dick, and R. M. Greenwood. 1980. Deoxyribonucleic acid homology among strains of Rhizobium trifolii and related species. Int. J. Syst. Bacteriol. 30:42-52.

11. Johnson, L. L. 1984. Nucleic acids in bacterial classification, p. 8-11. In N. R. Krieg and J. G. Holt (ed.), Bergey's manual of systematic bacteriology, vol. 1. Williams \& Wilkins, Baltimore.

12. Jordan, D. C. 1984. Family III. Rhizobiaceae. Genus I. Rhizobium Frank $1889,338^{\mathrm{AL}}$, p. $235-242$. In N. R. Krieg and J. G. Holt (ed.), Bergey's manual of systematic bacteriology, vol. 1. Williams \& Wilkins, Baltimore.

13. Jukes, T. H., and C. R. Cantor. 1969. Evolution of protein molecules, p. 21-132. In H. N. Munro (ed.), Mammalian protein metabolism. Academic Press, Inc., New York.

14. Laguerre, G., M. P. Fernanadez, V. Edel, P. Normand, and N. Amager. 1993. Genomic heterogeneity among French Rhizobium strains isolated from Phaseolus vulgaris. Int. J. Syst. Bacteriol. 43:761-767.

15. Lajudie, P. D., A. Willems, B. Pot, D. Dewettinck, G. Maestrojuan, M. Neyra, M. D. Collins, B. Dreyfus, K. Kersters, and M. Gillis. 1994. Polyphasic taxonomy of rhizobia: emendation of the genus Sinorhizobium and the description of Sinorhizobium meliloti comb. nov., Sinorhizobium saheli sp. nov., and Sinorhizobium teranga sp. nov. Int. J. Syst. Bacteriol. 44:715-733.

16. Martinez, E., M. A. Pardo, R. Palacios, and M. A. Cevallos. 1985. Reitera- 
tion of nitrogen fixation gene sequences and specificity of Rhizobium in nodulation and nitrogen fixation in Phaseolus vulgaris. J. Gen. Microbiol. 131:1779-1786.

17. Martinez-Romero, E., L. Segovia, F. M. Mercante, A. A. Franco, P. Graham, and M. A. Pardo. 1991. Rhizobium tropici, a novel species nodulating Phaseolus vulgaris L. beans and Leucaena sp. trees. Int. J. Syst. Bacteriol. 41: $417-426$.

18. Navarro, R. B., A. A. T. Vargas, E. C. Schröder, and P. van Berkum. 1993. Uptake hydrogenase (Hup) in common bean (Phaseolus vulgaris) symbioses. Appl. Environ. Microbiol. 59:4161-4165.

19. Piñero, D., E. Martínez, and R. Selander. 1988. Genetic diversity and relationships among isolates of Rhizobium leguminosarum biovar phaseoli. Appl. Environ. Microbiol. 54:2825-2832.

20. Segovia, L., P. W. Young, and E. Martinez-Romero. 1993. Reclassification of American Rhizobium leguminosarum biovar phaseoli type I strains as Rhizobium etli sp. nov. Int. J. Syst. Bacteriol. 43:374-377.

21. Stackebrandt, E., and B. M. Goebel. 1994. Taxonomic notes: a place for
DNA-DNA reassociation and 16S rRNA sequence analysis in the present species definition in bacteriology. Int. J. Syst. Bacteriol. 44:846-849.

22. van Berkum, P. 1990. Evidence for a third uptake hydrogenase phenotype among the soybean bradyrhizobia. Appl. Environ. Microbiol. 56:3835-3841.

23. van Berkum, P., R. B. Navarro, and A. A. T. Vargas. 1994. Classification of the uptake hydrogenase-positive $\left(\mathrm{Hup}^{+}\right)$bean rhizobia as Rhizobium tropici. Appl. Environ. Microbiol. 60:554-561.

24. Weisburg, W. G., S. M. Barns, D. A. Pelletier, and D. J. Lane. 1991. 16S ribosomal DNA amplification for phylogenetic study. J. Bacteriol. 173:697703.

25. Willems, A., and M. D. Collins. 1993. Phylogenetic analysis of rhizobia and agrobacteria based upon 16S rRNA gene sequences. Int. J. Syst. Bacteriol. 43:305-313.

26. Young, J. P. W. 1985. Rhizobium population genetics: enzyme polymorphism in isolates from peas, clover, beans, and lucerne grown at the same site. J. Gen. Microbiol. 131:2399-2408. 